\title{
Maratha Reservation in Maharashtra: A Challenge to the Principles of Equality
}

Kartik Agarwal*

\section{Abstract}

The Maharashtra Government has passed a Special Educational and Backward class Act, 2018 to provide additional reservation for Marathas. Article 15(4) and 16(4) authorizes the State to provide reservation for backward classes. However, the same has to be exercised in a very cautious manner. The judicial approach towards reservation has resulted in the evolution of numerous requirements that are mandated to be fulfilled, while providing reservation. This includes, inter alia, a ceiling limit of $50 \%$, inadequacy of representation and quantifiable data. Maratha reservation took the total reservation count in the state to $68 \%$, which is way ahead of the ceiling limit. The step was considered to be more towards appeasing politically influential Marathas than to do justice to them. Upon being challenged in Bombay High Court, the court upheld the reservation and gave a justification for the existence of extraordinary circumstances in favour of reservation for Marathas. This paper aims to constitutionally analyze the said Act, to understand whether the Marathas fulfil all the abovementioned yardsticks of 'backwardness'. The paper also aims to determine whether creating a separate class for Marathas is justifiable or not.

Keywords: Articles 15(4) \& 16 (4), Ceiling Limit, Extraordinary Situation, M G Gaikwad Commission, Socially and Educationally Backward Classes Act, 2018

\section{Introduction}

The Indian caste system is divided into four classes, based on their occupation, namely, Brahmins, Kshatriyas, Vaishyas, and Shudras. ${ }^{1}$

*National Law University, Jodhpur, India; kartik.agarwal254@gmail.com 
Shudras come at the lower strata in the hierarchy and thus, they were subjected to discriminatory behaviour by the upper castes. They were denied basic necessities, access to wells for drinking water and adding salt to the wound was the prevalence of untouchability. ${ }^{2}$ The right to equality is enshrined under Article 14 of the Constitution and is further extended by Article 15 and 16. It guarantees equality in all spheres of life including education, public employment, access to public places, etc. and prohibits any discriminatory behaviour on the grounds of race, caste, sex, religion, etc. However, given the caste system in India and the importance attached to the same, equality could not have been ensured in India, without improving the social standing of these backward classes. Therefore, the idea of 'Affirmative Action' was advocated by Dr. B.R. Ambedkar, who himself was a Dalit. Affirmative action refers to the measures taken to remedy discrimination and under-representation suffered by certain sections of people, in the past. ${ }^{3}$ It provides a head start to the marginalized people, who have suffered discrimination, by providing them reservation, with respect to public employment and education.

Over the last few years, the policy of 'Affirmative Action' has been grossly misused in India. It mainly acts as a tool for gaining political mileage. The demand for reservation by various castes in India, like the Gujjars in Rajasthan, Marathas in Maharashtra, Kapus in Andhra Pradesh and Jats in Haryana, has increased manifold in the last decade. This paper emphasizes on the Maratha reservation, which was brought into effect by the socially and Educationally Backward Classes Act, 2018 [hereinafter SEBC Act, 2018]. A separate class, named Special Educational and Backward class, was created on the recommendations of the M.G. Gaikwad Commission, to provide $16 \%$ reservation to Marathas. This step has

1 A.N. Bose, Evolution of Civil Society and Caste System in India, 3(1) INTERNATIONAL REVIEW OF SOCIAL HISTORY 103 (1958).

2 Raj S. Gandhi, The Practice of Untouchability: Persistence and Change, 10(1) HumboldT JOURNAL OF SOCIAL RELATIONS 255 (1982).

3 William G. Tierney, The Parameters of Affirmative Action: Equity and Excellence in the Academy, 67(2) REVIEW OF EDUCATIONAL RESEARCH 167 (1997). 
attracted a lot of hue and cry, as after $16 \%$ reservation, the total reservation count in the State had reached $68 \% 4$, which was against the $50 \%$ ceiling limit imposed by the Hon'ble Supreme Court in Indira Sawhney case $^{5}$. The Bombay High Court upheld the reservation in favour of Marathas, with a slight reduction in reservation from $16 \%$ to $12 \%$ in education, and $13 \%$ in jobs. Six questions have been raised over the legislative intent behind this step. Was there any need to take such a step or was it merely a political gimmick? Further, has the Court also made an error by upholding the said reservation? Hence, the purpose of this paper is to analyze the said model of reservation and decide upon its correctness under the Indian Constitution.

The first part of the paper explains the reservation policy provided under Article 15(4) and 16(4) of the Constitution and the jurisprudence that has evolved over the implementation of this policy. Then it highlights the legislative history of the Maratha reservation and constitutionally analyses the Maratha reservation, to point out the areas where it goes against the constitutional values. This is followed by suggestions which are required to be adopted by the State to fix the problem of never-ending demand for reservation, effective implementation of the reservation policy and to restore the lost faith of the people, in the reservation process.

\section{India and Reservation under Article 15(4) and 16(4)}

The right to equality is guaranteed under Article 14 to 18 of the Indian Constitution. The doctrine of equality before the law is a necessary corollary that permeates the Indian Constitution. ${ }^{6}$ Article 14 provides for two concepts, namely, 'equality before the law' and 'equal protection of laws' wherein, the former is a negative concept and the latter is a positive one. 'Equality before law' prohibits

4 PTI, Reservation for Marathas cleared, now Maharashtra has $68 \%$ quota, BUSINESS STANDARD (November 30, 2018, 12:58 AM), https://www.business-standard.com/article/current-

affairs/reservation-for-marathas-cleared-now-maharashtra-has-68quota-118112900474_1.htmlwhat

${ }^{5}$ Indira Sawhney v. Union of India, AIR 1993 SC 477.

${ }^{6}$ Ashutosh Gupta v. State of Rajasthan, AIR 2002 SC 1533.

7 M.P. JAIN, INDIAN CONSTITUTIONAL LAW 879 (7th ed., 2016). 
conferring of any special privilege in favour of any person, irrespective of his condition, whereas 'equal protection of laws' confers an obligation upon the state to establish equality in the society, through the machinery of law. ${ }^{8}$ It also requires the state to provide substantially equal opportunities to those who are placed unequally. ${ }^{9}$

Article 15 takes this concept of equality further and prohibits discrimination by the state on various grounds, namely, religion, race, caste, sex and place of birth. However, clause (4) of Article 15 accords an extra tool to the state and allows it to make any provision for the advancement of any socially and educationally backward classes of citizens, or the scheduled caste and scheduled tribes. Article 15(4) seems to be an exception to Article 15(1). Similarly, Article 16(4), which provides for reservation of appointments in services to the backward classes, seems to be an exception to Article 16(1), which provides for equality of opportunity in employment. The air regarding this has been cleared by the court in the case of State of Kerala v. N.M. Thomas ${ }^{10}$, wherein the court said that Article 15(4) and 16(4) are not exceptions and are rather special provisions for achieving right to equality. It can therefore, be said that Article 15(4) and 16(4) are supplementary to Article 15 and 16 respectively, than being an exception to them.

While making a ground breaking observation, the Hon'ble Supreme Court in Indira Sawhney case ${ }^{11}$ held that a cap of $50 \%$ is required to be maintained for reservation under Article 15(4) and 16(4), and it should not be breached unless there exists some extraordinary situation. However, the state of Tamil Nadu $(50 \%$ OBCs, $18 \%$ SCs, $1 \%$ STs) ${ }^{12}$ has breached this cap owing to the presence of an extraordinary situation. Recently, Rajasthan has also

\footnotetext{
8 Sri Srinivasa Theatre v. Govt. of Tamil Nadu, AIR 1992 SC 1004.

${ }^{9}$ Supra, note 5.

10 State of Kerala v. N.M Thomas, AIR 1976 SC 490.

11 Supra note 5

12 The Tamil Nadu Backward Classes, Scheduled Castes and Scheduled Tribes (Reservation of Seats in Educational Institutions and Appointments or Posts in the Services Under the State) Act, 1993, http://www.lawsofindia.org/pdf/tamil_nadu/1994/1994TN45.pdf.
} 
breached the $50 \%$ cap by providing $5 \%$ reservation to five communities, namely the Gujjars, Banjaras, Gadia Lohars, Raikas and Gadarias, which took the total reservation count in the state to $54 \% .{ }^{13}$ A very similar model has been adopted by the Maharashtra government, by introducing $12 \%$ and $13 \%$ reservation in favour of Marathas, which has been discussed in the next part of the paper.

\section{Maratha Reservation and its Legislative History}

Marathas are considered to be an influential class in Maharashtra and till date, the highest number of Chief Ministers in the state, hail from this category. Historically, Marathas, like Shivaji, have ruled Maharashtra for a long period and have also constituted a large proportion in the army of Peshwas and the English. The quest for reservation among Marathas in Maharashtra, had started long back when two commissions, namely, Khatri Commission and Bapat commission, were constituted in 1995 and 2008 respectively, and both had recommended not to include Marathas in the Other Backward Class [hereinafter OBC] category. ${ }^{14}$ The Mandal Commission, which was constituted to identify socially or educationally backward classes in India, had also declared Marathas to be a 'forward class'. ${ }^{15}$ However, some years later in 2015, 16\% reservation was recommended for the Marathas by Narayan Rane Commission [hereinafter Rane Commission]. Based upon the recommendations of the Rane Commission, Maharashtra government has come up with an ordinance, wherein they have reserved $16 \%$ seats in educational institutions and jobs for Marathas and $5 \%$ seats for Muslims. ${ }^{16}$ The ordinance was stayed by

13 Rajasthan Government grants quota for Gujjars, THE HINDU (Aug.18,2017,), https://www.thehindu.com/news/national/otherstates/rajasthan-govt-grants-quota-for-gujjars/article19519157.ece.

14 Faizan Mustafa, Maratha reservation is more appeasement than justice, THE HINDU (July 10, 2019), https://www.thehindu.com/opinion/oped/more-appeasement-thanjustice/article28335545.ece/amp/?_ twitter _impression=true.

$15 \mathrm{Id}$

16 Swati Deshpande, Bombay HC stays Maharashtra govt's decision to give $16 \%$ reservation to Marathas, THE TIMES OF INDIA (Nov. 15, 2014, 5:56 AM), https://timesofindia.indiatimes.com/india/Bombay-HC- 
the Bombay High Court on the ground that it was in breach of the ceiling limit of $50 \%$ and there was no extraordinary situation to justify the breach. ${ }^{17}$ The court has relied on a well-settled principle that "the rule of $50 \%$ was a binding rule and not a mere rule of prudence". 18

Agitations in Maharashtra for Maratha reservation have not stopped with the Bombay High Court judgment. Marathas have continued to exert pressure on the state government by various means, such as by organizing massive rallies, destructing public property, obstructing rail services, resorting to violence, etc. ${ }^{19}$ This had forced the State government to constitute the M.G. Gaikwad commission to identify the backwardness of the Marathas in 2017, which submitted its report in 2018, with a recommendation to declare Marathas as 'socially and educationally backward community'. The government has effectuated the recommendation made by the commission and passed the SEBC Act, 2018 for reserving $16 \%$ seats in educational institutions and jobs for Marathas ${ }^{20}$. This took the total reservation count in the state to $68 \%$, which was above the ceiling limit of $50 \%{ }^{21}$. Thus, it was challenged in the Bombay High Court in the case of Jishri Laxmanrao Patil $v$. State of Maharashtra22 wherein the court has upheld the Constitutional validity of the SEBC Act, 2018. However, the court has reduced the quantum of reservation from $16 \%$ to $12 \%$ in education and $13 \%$ in jobs, as $16 \%$ reservation was not justifiable. ${ }^{23}$

stays-Maharashtra-govts-decision-to-give-16-reservation-to-

Marathas/articleshow/45144686.cms.

17 Sanjeet Shukla v. State of Maharashtra, 2014 SCC Online Bom 1672.

18 Id. at 23.

19 Sporadic violence in Maharashtra after Marathas protest for reservation, HiNDUSTAN TIMES (July 25, 2018, 9:38 PM), https:// www.hindustantimes.com/india-news/sporadic-violence-inmaharashtra-after-marathas-protest-for-reservations/story-DIpee C4f Ah1 KLUq5NJGDaK.html.

20 Supra, note 4

$21 \mathrm{Id}$.

22 Supra, note 6

23 Id. 
The government's move in the State of Maharashtra is considered to be a politically motivated action. A question arises whether the Bombay High Court was correct in upholding the Constitutional validity of the SEBC Act, 2018. The author in the next part of the paper attempts to answer this question.

\section{Violation of ceiling limit and extraordinary situation}

Dr B.R. Ambedkar is considered as the Father of the Indian Constitution. Being a Dalit, he was a staunch proponent of reservation. During the debate on Article 10(1) and 10(3), which corresponds to Article 16(1) and 16(4) of the Indian Constitution, Dr Ambedkar remarked about the adequate representation of various classes in services - "Therefore the seats to be reserved, if the reservation is to be consistent with Sub-clause (1) of Article 10, must be confined to a minority of seats. It is then only that the first principle could find its place in the Constitution and effective in operation" ${ }^{24}$ The opinion of Dr B. R. Ambedkar depicts very clearly that he always wanted to maintain a balance between equality of opportunity mentioned under Article 16(1) and reservation in favour of the backward class under Article 16(4), for efficiently achieving the basic purpose behind Article 16(1).

The Hon'ble Supreme Court has also dealt with the question of quantum of reservation in the landmark case of M.R. Balaji v. State of $\mathrm{Mysore}^{25}$, wherein the court has fixed the ceiling limit of $50 \%$ for reservation under Article 15(4) and asserted that providing reservation beyond $50 \%$ would nullify the purpose behind Article 15(1). Application of the ceiling limit of $50 \%$ has been extended to Article 16(4) by the court in Indira Sawhney case ${ }^{26}$. Further, the court observed in Indira Sawhney case that the ceiling limit of 50\% is not rigid and it can be relaxed in case of extraordinary situation such as

24 CONSTITUENT ASSEMBLY DEBATES, Vol. VII, November 30, 1948 (proceedings), speech by DR. B.R. AMBEDKAR 701-02, https:/ / www.constitutionofindia.net/constitution_assembly_debates/v olume/7/1948-11-30

${ }_{25}$ M.R. Balaji v. State of Mysore, AIR 1963 SC 649.

26 Supra, note 5 . 
in far-flung areas where the conditions are peculiar and life is cut off from the mainstream. ${ }^{27}$

While upholding Maratha reservation, the Bombay High Court said that there exists an extraordinary situation in Maharashtra for reservation in favour of Marathas and thus, crossing the ceiling of $50 \%$ is justified. The court has relied on various observations made by the M.G Gaikwad commission, such as the inability to raise the standard of living of Marathas, an increase in the number of suicides committed in the region by Maratha farmers, substantial backlog in the services, suicide committed by the daughters of farmers, etc. However, the factors considered by the M.G. Gaikwad commission are highly controversial, as they do not depict the social and educational backwardness that Article 15(4) and 16(4) provides for. The commission took note of the fact that amongst 13368 suicides committed in Maharashtra, 2152 were committed by Marathas, 28 however, the reason for the same is not backwardness, but the agrarian crisis prevailing across the nation. Similarly, the suicide committed by daughters of Maratha farmers does not reflect their social and educational backwardness. Social backwardness refers to the extreme marginalization that a group of people suffer in terms of social status. ${ }^{29}$ The Marathas did not face any kind of marginalization in the state and thus, they cannot be considered as socially backward.

The commission has also disregarded other pertinent factors which would have negated the possibility of classifying Marathas as socially and educationally backward. Marathas hold around 19\% share in government jobs, $15 \%$ in IAS, $28 \%$ in IPS and $17 \%$ in IFS cadre with a $30 \%$ share in the total population of the state. ${ }^{30}$ The handsome amount of share that Marathas have in the government jobs and administrative services of the state, cannot be considered as inadequate representation. Further, since 1962, more than $50 \%$ of MLAs in the Maharashtra legislative assembly are Marathas among 200 sugar factories in the state, 168 are controlled by Marathas, more than $70 \%$ of the cooperative banks have heads

27 Id. at 859.

28 Supra, note 16.

29 Supra, note 5 .

30 Supra, note 6 . 
from Maratha community. ${ }^{31}$ These factors very well highlight that the M.G. Gaikwad Commission report suffers from a fundamental flaw. Even the Bombay High Court has erred in upholding the validity of the report and acknowledging these factors, as a sign of exceptional circumstances.

\section{Absence of quantifiable data}

Article 16(4) permits the State to provide reservation in favour of any backward class, if in the opinion of the State it is inadequately represented in the services of the State. It means that while providing reservation, the State should consider backwardness and inadequacy of representation of the class $^{32}$ and further, the reservation should be based upon adequate contemporaneous quantifiable data ${ }^{33}$. The ceiling limit does not remain a restriction and can be breached if the reservation is based upon some adequate quantifiable data. ${ }^{34}$ In this process, due consideration is also required to be given to the overall administrative efficiency of the State. ${ }^{35}$

M.G. Gaikwad report was primarily based on rural data and mere 950 urban families were considered in the report, which even excluded Mumbai. ${ }^{36}$ Further, the total sample size taken by the report, consists of merely 43,692 individuals, which represent only $0.2 \%$ of the total State population of around 11.5 crores and $68 \%$ of the total people surveyed by the commission were Marathas. As mentioned above, the Maratha community has around 19\% share in the State services, which suffices the requirement of adequate

31 Shubhnagi Khapre, Did Maharashtra need a Maratha quota?, THE INDIAN EXPRESS ( June 27, 2014, 11:09 AM), https:// indianexpress.com/ article/india/politics/did-maharashtra-need-a-maratha-quota. S.M. Dahiwale, Consolidation of Maratha Dominance in Maharashtra, 30(6) ECONOMIC AND POLITICAL WEEKLY 341 (1995); Supra Note 15

32 Ashok Kumar Thakur v. Union of India, (2008) 6 SCC 1.

33 Ram Singh v. Union of India, (2015) 4 SCC 697.

34 Supra, note 30.

${ }^{35}$ M Nagraj v. Union of India, (2006) 8 SCC 212.

36 Sailee Dhayalkar, Agencies that surveyed Marathas lacked experience, Bombay HC told, THE INDIAN EXPRESS (February 16, 2019, 3:51 AM), https://indianexpress.com/article/cities/mumbai/agencies-thatsurveyed-marathas-lacked-experience-bombay-hc-told-5586628/. 
representation in the state services. Moreover, reserving $12 \%$ and $13 \%$ seats in favour of Marathas, who have a 30\% share in the total population of the State will take the total reservation count to $64 \%$ and $65 \%$ and thus, will directly affect the overall administrative efficiency of the State.

The Khatri, Bapat and Mandal Commissions have categorized Marathas as a forward community and Gaikwad Commission does not put forward any quantifiable data based upon which Marathas can be classified as backward. Moreover, the Gaikwad commission report suffers from the vices of arbitrariness, as it does not show any compelling reasons for the State to introduce such reservation. Thus, the ceiling limit of $50 \%$ cannot be violated based on this report, as it would directly impinge upon the equality of the citizens of the State

\section{Separate class for Marathas}

The Hon'ble Supreme Court in the M.R. Balaji case $^{37}$ had restricted further division of the backward class into backward and more backward class. However, the same has been overruled in the Indira Sawhney case38, wherein the court has allowed further division of backward classes. Further, the Court in Indira Sawhney case $^{39}$ had acknowledged the fact, that the Hindu community is divided based on caste and therefore, it will not be possible to keep the reservation policy immune to the caste system. Therefore, it allowed caste to be considered as one of the factors in determining backward class, but it cannot be the sole criterion for the same.

In Ram Singh $v$. Union of India ${ }^{40}$, the reservation was provided to the Jat community of nine states, by classifying them under the $\mathrm{OBC}$ category in the Central List. The court had declared the said reservation to be unconstitutional, as it was based merely upon the caste criterion. ${ }^{41}$ Similarly, the reservation in favour of five castes in the state of Rajasthan, which were the Banjaras, Gadalias, Gujjars,

\footnotetext{
37 Supra, note 7

38 Supra, note 5

${ }^{39}$ Id.

${ }^{40}$ Supra, note 35.

$41 \mathrm{Id}$.
} 
Rebaris and Gadarias ${ }^{42}$, where the castes were classified as Special Backward class, was struck down as the reservation was provided solely based on caste criterion. ${ }^{43}$ In the state of Maharashtra as well, the same formula was adopted by the legislature, to provide reservation in favour of Marathas. A special category, which consists of only Marathas, was formed merely based on caste criterion and thus, it falls foul of the constitutional principles propounded by our Constitutional framers and the apex court.

Article 14 provides for equality before the law. However, it is an accepted fact that none of the fundamental rights in our Constitution are absolute in nature, as is the case with Article 14. Article 14 forbids class legislation, but it does not forbid reasonable classification. ${ }^{4}$ Two conditions are required to be satisfied for a reasonable classification, namely, the differentiation between those who are grouped and others should be based upon an intelligible differentia and that differentiation must have a relation or nexus with the object sought to be achieved by the Act. ${ }^{45}$ In other words, no privileges can be conferred upon a certain class of people, who are arbitrarily selected out of a large number of similarly situated people, as it would bring inequality and thus, would be violative of Article 14. ${ }^{46}$ Even if the Marathas are considered as backward, they should have been included within the OBC category, rather than being classified under a separate class. Creating a separate class for providing reservation to Marathas does not reflect any intelligible differentia or rational nexus with the object sought to be achieved by such reservation and thus, the said classification amounts to class legislation and violates Article 14.

425 castes, including Gujjars, re-included in OBC list in Rajasthan https://www.financialexpress.com/india-news/5-castes-includinggujjars-re-included-in-obc-list-in-rajasthan/677292/

43 Captain Gurvinder Singh v. State of Rajasthan, 2016 SCC Online Raj 8306.

44 State of West Bengal v. Anwar Ali Sarkar, AIR 1952 SC 75.

45 Budhan v. State of Bihar, AIR 1955 SC 191.

46 Supra, note 38. 


\section{Overturning the earlier judicial decision}

Indian democracy rests upon three pillars, namely, judiciary, legislature, and executive. None of these working units interferes in each other's work, owing to the existence of the doctrine of separation of power, which also constitutes a part of the basic structure of the Constitution. ${ }^{47}$ Strict separation of power is not possible in a large democracy like India and therefore, the Constitution provides for certain checks and balances over their powers. The judiciary enjoys the power to invalidate the law of the legislature, if the law transgresses the Constitutional boundaries and similarly, the legislature enjoys the power to overturn the judgment of the court, by curing the defects or removing the cause of invalidity. ${ }^{48}$ The law has to be altered by the legislature in such a manner that after the change it would not be possible for the judiciary to arrive at the same conclusion. ${ }^{49}$

An ordinance was passed by the Maharashtra government based on the Narayan Rane committee report in 2014, to grant $16 \%$ reservation to the Marathas. When the matter reached the Bombay High Court, the court stayed the ordinance in Sanjeet Shukla case $e^{50}$, as there were no extraordinary circumstances to justify the breach of the $50 \%$ cap on the reservation. ${ }^{51}$ The court has considered the fact that though the Marathas have originated from the Kunbis caste, now they are a socially, politically and educationally influential caste and thus, they cannot be classified as backward. ${ }^{52}$ Subsequently, the Maharashtra government has granted reservation to Marathas by creating the SEBC Act, 2018 and as a result, made the judicial pronouncement made by the court in Sanjeet Shukla case 53 ineffective. However, the defect of the nonexistence of any extraordinary circumstances required for surpassing the ceiling limit of $50 \%$, has not been cured by the

\footnotetext{
${ }^{47}$ Keshavananda Bharati v. State of Kerala, AIR 1973 SC 1461.

48 Bakhtawar Trust v. M.D. Narayan, (2003) 5 SCC 298.

${ }^{49}$ Goa Foundation v. State of Goa, (2016) 6 SCC 602.

50 Supra, note 19

51 Id.

$52 \mathrm{Id}$. at 55

53 Id.
} 
legislature and thus, the action of the legislature to overturn the judicial decision, is unlawful in nature.

\section{The Efficiency of the Administration.}

The Hon'ble Supreme Court had held in the case of M. Nagraj $v$. Union of Indias4, that while providing reservation, the State is required to look into the existence of compelling reasons, such as overall administrative efficiency. Reserving $12 \%$ and $13 \%$ seats in favour of Marathas, who have just a $30 \%$ share in the total population of the State, will take the total reservation count to $64 \%$ and $65 \%$. Further, reserving the majority of the seats for backward classes will restrict the entry of the general meritorious class in public employment and therefore, it will directly affect the efficiency of the operations in the State. .5

This shows that Marathas do not satisfy the criteria contemplated by the Hon'ble Supreme Court for being classified as backward. The SEBC Act, 2018 passed by the Maharashtra government suffers from various fundamental flaws and the Bombay High Court has also erred in upholding the constitutional validity of the SEBC Act, 2018.

\section{Suggestions}

According to the Mandal commission report, around $74 \%$ of the Indian population come under the category of 'backward class' (inclusive of SC, ST, and OBC). ${ }^{56}$ If the remaining sections of the country also start demanding reservation, then a situation will arise where the whole nation would have to be categorized as backward and that situation would be worse than a nightmare for a developing country like India. Therefore, resolving this grave issue of reservation should be of paramount concern for the government. The following suggestions can be considered by the State of Maharashtra, as well as other parts of the nation that are grappling with the issue of rising demand for reservation. The suggestions would also help in bringing more transparency in the law-making

\footnotetext{
${ }^{54}$ M. Nagraj v. Union of India, (2010) 12 SCC 526

${ }^{55}$ Supra, note 33.

56 Supra Note 5
} 
process and would reinstate the lost faith of the people in this process.

\subsection{Need to curb the never-ending demand for reservation}

Marathas are an influential political class in the State of Maharashtra. Agitation for reservation had started long back and since then, successive governments that occupied office had tried to satisfy the demand in their way. This attempt came to an end recently in 2019, with the legislation of the SEBC Act, 2018 and its affirmation by the Bombay High Court. Demand for reservation by Marathas is not the first of its kind. Such demands are being continuously raised by multiple castes across the nation. This includes demand by Gujjars in Rajasthan, Jats in Haryana, Patidars in Gujarat and Kapus in Andhra Pradesh. ${ }^{57}$ It has been around 70 years since we have been following the reservation policy and since then the reservation has increased from a minority share to $50 \%$ and has even crossed $50 \%$ in some States. It is a never-ending process. If today one caste is protesting for being categorized as backward, tomorrow another caste will agitate for the same reason.

The Apex Court has held in C.A. Rajendran v. Union of India ${ }^{58}$, that Article 16(4) neither imposes any constitutional duty on the government to provide reservation nor confers any fundamental right on any individual to claim reservation. The State government is not bound to genuflect before the demands of the protesting community. Rather, they should endeavour to find some other way to deal with the backwardness of any individual or community as otherwise, it would impair the rights of the general meritorious classes.

An alternative to the reservation scheme could have been procedural and implementation related improvement in the government schemes. Mr Rajiv Gandhi, the former Prime Minister

57 Swanithan S Anklesaria Aiyar, Aspirational India may turn against Narendra Modi, THE ECONOMIC TIMES, (February 28, 2016, 11:06 AM), https://economictimes.indiatimes.com/news/politics-and-nation/ aspirational-india-may-turn-against-narendra-modi/articleshow / 51175343.cms? from $=$ mdr.

58 C.A. Rajendran v. Union of India, AIR 1968 SC 507. 
of India, once opined that when the Central government releases Rs. 1, only 15 paise reaches the needy. ${ }^{59}$ The government has already put in place various schemes for extending help in the form of scholarships to students, minimum support price for the farmers, etc. The only need is to implement these government schemes properly and make an attempt to bring the unequal on an equal pedestal vis-a-vis other people in society. So, the Maharashtra government is firstly expected to attempt to solve the grievances faced by the Marathas, by other means such as by providing additional financial assistance to farmers who are facing critical financial hardships or providing scholarships to the students, who belong to the financially weaker section of the society. This will help in alleviating the problems of Marathas, without resorting to extreme measures like reservation.

\subsection{One Time reservation}

Reservation policy in the form of affirmative action for Scheduled Caste and Scheduled Tribes, was initially adopted by India for a period of ten years and the same was to be reconsidered after ten years. ${ }^{60}$ However, the reconsideration has not yet been done. Reservation is provided to help the backward class in achieving an equal status vis-à-vis forward class in the society. It is a misuse of this process when reservations are provided repeatedly across generations of families. For example, if a person in a family becomes an IAS officer then he/she becomes a socially, educationally and financially forward person and no more remains backward. His/her children will also be in a position to avail themselves of all the opportunities which any other ordinary children from the forward class are availing and therefore, carrying forward the reservation to his/her child and grandchild will deprive other general meritorious people of their opportunities.

59 PTI, 'Only 15 paise reaches the needy': SC quotes Rajiv Gandhi in its Aadhar Verdict, HiNDUSTAN TIMES (June 11, 2017, 05:52 PM), https://www.hindustantimes.com/india-news/only-15-paise-reachesthe-needy-sc-quotes-rajiv-gandhi-in-its-aadhaar-verdict/storyI8dniDGXF6ksulggTDgb9L.html.

${ }^{60} I X$, Constituent Assembly Debates: Official Report, 24 ${ }^{\text {th }}$ August, 1949, https://www.constitutionofindia.net/constitution_assembly_debates/v olume/9/1949-08-24 
Therefore, a one-time reservation policy is required to be adopted, wherein the benefits of reservation can be availed by only one generation in a family. This will help in percolating the benefits of reservation to the people who are in real need of it and preventing its use to the detriment of the general meritorious people.

\subsection{Need for the creamy layer policy}

The creamy layer refers to the affluent people among the backward or disadvantaged sections of the society. They are socially, educationally and economically well off. To keep these privileged classes out of the benefits of reservation, a financial ceiling limit is imposed over them which is known as 'means test' or 'creamy layer test'. The test of the creamy layer is not included in the SEBC Act, 2018. This makes the reservation open to even the advanced sections of the society and leads to the abolition of the whole idea behind introducing the policy of affirmative action. Therefore, it is necessary to introduce the creamy layer test in determining backwardness among Marathas.

\subsection{Reports of the Backward Commission to be made public}

The SEBC Act, 2018 was legislated by the State of Maharashtra on the recommendations of the M.G. Gaikwad Commission report. Surprisingly, the report was never made available in the public domain. The Maharashtra government gave an excuse that the report contains Maratha community's history and thereby, release of the report in public domain may result in communal tension and disruption of law and order in the State. ${ }^{61}$ However, the State cannot make such a baseless excuse as openness and transparency are considered to be an important element of the rule of law. Further, the Right to receive information has been recognized as a facet of the Freedom of speech and expression under Article 19(1)(a) of the Constitution. ${ }^{2}$ Right to Information Act, which was legislated by the government in 2005, aimed to ensure greater

61 Sonam Saigal, Hand over full Commission report on Maratha quota to public: HC, THE HiNDU (January 19, 2019, 01:06 AM), https:// www. The hindu.com/news/cities/mumbai/hand-over-full-commission-report-onmaratha-quota-to-public-hc/article26115320.ece.

62 PUCL v. Union of India, (2003) 4 SCC 399. 
transparency, accountability, and promotion of citizen. ${ }^{63}$ Thus, the government is obliged to make the report public as otherwise it would strike directly upon the right of the people to receive information and would turn the whole rulemaking process suspicious. Further, releasing such reports in public will strengthen the faith of the public in the law-making process and make people realize that reservation is provided only on the basis of some quantifiable data and not merely to meet someone's political end.

\section{Conclusion}

This paper discusses the existing situation on Maratha reservation, in the State of Maharashtra. The hue and cry over the Maratha reservation has come to an end, with the legislation of the SEBC Act, 2018 by the State legislature. A lot of questions have been raised over the constitutional validity of the said legislation, as it has taken the total reservation count to $68 \%$ and therefore, the same was challenged. The settled position is that reservation cannot exceed $50 \%$ unless there exist some exceptional circumstances. The Bombay High Court has upheld the validity of the SEBC Act, 2018 and has provided $12 \%$ reservation in education and $13 \%$ reservation in jobs, in favour of the Marathas.

The author has attempted to analyze whether the Maratha reservation stands correct with respect to the Constitutional benchmarks. The answer to the same seems to be in the negative as there does not exist any extraordinary circumstance, which can justify the violation of the ceiling limit of $50 \%$. Further, it also suffers from various other infirmities such as the absence of quantifiable data, overturning the earlier judicial decision, creating a separate class for Marathas, and undermining administrative efficiency. According to the author, Marathas cannot be classified as backward on the basis of the existing data provided in the report. Even if the data of the report is relied upon and Marathas are conceded to be backward, they should ideally be included under the category of $\mathrm{OBC}$ and creation of a separate class for providing them reservation is totally unjustifiable. The author has then provided some suggestions that can be adopted by the

63 Namit Kumar v. Union of India, (2013) 1 SCC 745. 
government in order to tackle this situation. Further, the suggestions provided above will also assist the State in better implementation of the reservation policy and reinstate the lost faith of the people in the reservation process. Suggestions include holding the never-ending demand for reservation, coming up with one-time reservation, inclusion of the 'creamy layer' test in reservation and making the report of backward commissions public to ensure transparency in the process.

Reservation was given a place in our Constitution under the principle of Affirmative Action, with an intention to provide a helping hand or elevation to the backward class and to bring them on the same pedestal as the forward class of the nation. This policy was never intended to be permanent by the Constitutional makers and was to be reconsidered after ten years of coming into existence. However, political interests have never made this to happen and as a result, now the reservation is claimed as a matter of right by various castes. Protests for claiming reservation have now become a routine affair and no part of the nation is left untouched by its vices. It not only hinders the national economy, but also impinges upon the fundamental right to equality of the people. The government has also failed to percolate the benefits of reservation to the underprivileged sections of society. Therefore, the State should consider the above changes while granting reservation, otherwise the time is not far when the whole nation will stake claim as 'backward', in an attempt to become 'forward'. 